
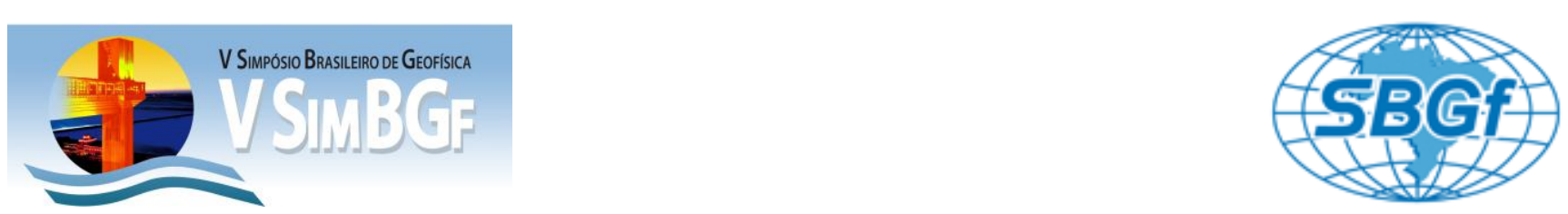

\title{
Mineralogical and petrophysical characterization of stromatolite from Salgada lagoon, Campos dos Goytacazes (RJ), Brazil.
}

Nathaly L. Archilha* - nathy0305@gmail.com

Roseane M. Misságia, Marco A. R. de Ceia and Irineu A. Lima Neto.

Laboratório de Engenharia e Exploração de Petróleo (LENEP) - Universidade Estadual do Norte Fluminense (UENF)

\section{Copyright 2012, SBGf - Sociedade Brasileira de Geofísica}

Este texto foi preparado para a apresentação no V Simpósio Brasileiro de Geofísica, Salvador, 27 a 29 de novembro de 2012. Seu conteúdo foi revisado pelo Comitê Técnico do V SimBGf, mas não necessariamente representa a opinião da SBGf ou de seus associados. É proibida a reprodução total ou parcial deste material para propósitos comerciais sem prévia autorização da SBGf.

\section{Summary}

Approximately $60 \%$ of oil and $40 \%$ of gas world reserves are in carbonate reservoirs. These reservoirs are heterogeneous with a textural variety and typically fractured, leading to low recovery factors and also complex relationships between rock properties and geophysical data (Vanorio et al, 2008). Studies of these reservoirs have become very important in Brazil after 2005, when Petrobras announced a large carbonate reserve in the pre-salt region of Santos basin. The reservoir characterization requests a better understanding of the relationship between geology, petrophysical and acoustic properties.

In this work, we made a mineralogical and petrophysical characterization of a stromatolite from Salgada lagoon. Measurements of X-ray diffraction (XRD) and scanning electron microscopy (SEM) showed that the stromatolite is composed mainly by high-magnesian calcite (HMC), with a small amount of aragonite and quartz. The thin section observation revealed the presence of skeletal material (shells), quartz grains and some regions that suggest recrystallization of high-magnesian calcite into low-magnesian calcite (LMC). The porosity of this sample is approximately $20 \%$, as measured with a gas porosimeter, and these pores have different shapes and sizes, as observed with a polarizing petrographic microscope. Using a rock physical system it was possible to measure the traveltime of $P$ wave and thus determine the velocity, which is slightly higher than $3000 \mathrm{~m} / \mathrm{s}$.

\section{Introduction}

Stromatolites are lithified and biosedimentary structures that grow through layers of sediments trapped by the carbonates' precipitation (Altermann \& Kazmierezak, 2003). This specific stromatolite was obtained from the Salgada lagoon outcrop. This is a hypersaline lagoon that has an area of $\sim 16 \mathrm{~km} 2$ and is located on the Campos dos Goytacazes coast, state of Rio de Janeiro, Brazil. The great similarity of this stromatolite with some Brazilian pre-salt reservoirs, as shown in Figure 1, leads such interest on studying it.

These carbonate reservoirs consists on a mixture of three dominant precipitations, related to three carbonate factories: T, M and C (Schlanger, 2005). The element's occurrence and distribution of these factories (fractures, pore types and mineralogy, for example) are closely linked to the rock's petrophysical properties (Dürrast \& Siegesmund, 1999). The rock's porosity and bulk density are the main factors that influence the seismic velocities (Rafavich et al, 1984). Therefore, the characterization of carbonate reservoirs by studying the rock mineralogy, petrophysical and acoustic response provides a fundamental understanding of reservoirs petrophysical response to geological features and its dynamic changes.

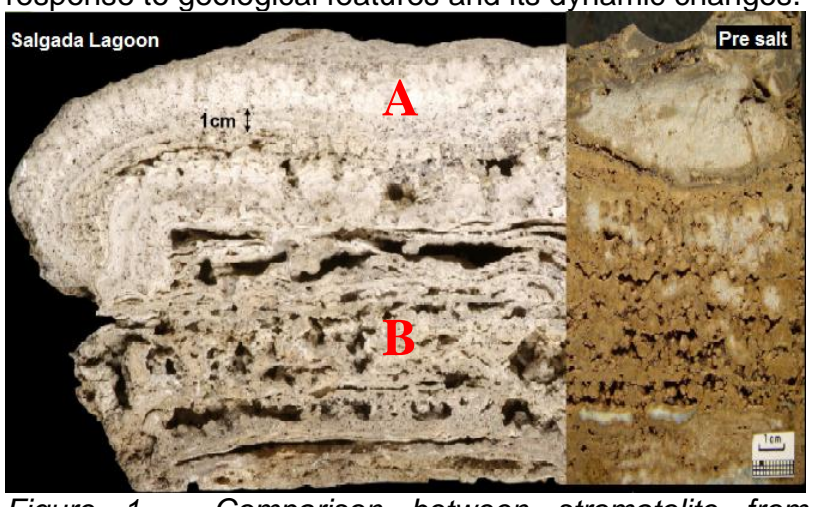

Figure 1 - Comparison between stromatolite from Salgada lagoon (left) and a core sample from the pre-salt of Santos basin (right). Section $A$ and $B$ indicates the two similar regions studied. Figure adapted from Estrella (2008) appud Papaterra (2010).

\section{Carbonate mineral composition}

There are four main minerals (Table 1) in carbonate rocks: calcite, magnesian calcite, aragonite and dolomite. Magnesian calcite can be classified into high magnesian calcite (HMC) and low magnesian calcite (LMC), depending on the molar concentration of magnesium carbonate $\left(\mathrm{MgCO}_{3}\right)$. Each mineral has a specific crystalline system, which is related to the atomic spatial distribution.

Table 1 - Some information of the four main minerals in carbonates rocks. Table adapted from Flügel (2010).

\begin{tabular}{|c|c|c|c|}
\hline & $\begin{array}{c}\text { Crystalline } \\
\text { system }\end{array}$ & $\begin{array}{c}\mathrm{Mol} \% \\
\mathrm{MgCO}_{3}\end{array}$ & Stability \\
\hline $\begin{array}{l}\text { Calcite } \\
\text { LMC }\end{array}$ & Trigonal & $<4$ & Stable \\
\hline HMC & Trigonal & $>4 \sim 30$ & Metastable \\
\hline Aragonite & $\begin{array}{c}\text { Orthorhombi } \\
\text { c }\end{array}$ & Very low & Metastable \\
\hline Dolomite & Trigonal & $40-50$ & Stable \\
\hline
\end{tabular}

The mineralogical stability is related to the ability of mineral to undergo transformation. A metastable system will remain the same in absence of external or internal 
influence. Oppositely, if this influence exists, the system transits to a stable state of lower energy.

\section{Carbonate factory}

The distribution and quantity of carbonate producer organisms are highly dependent on environmental factors, such as light and water temperature. All large accumulations are mixtures of three types of precipitation, which are related to the three systems factory: tropical $(\mathrm{T})$, mud-mound $(\mathrm{M})$ and cold $(\mathrm{C})$. Figure 2 shows the carbonate production rate of each fabric according to the precipitation depth and Figure 3 shows the relationship between mineralogical composition and carbonate rock factories. Stromatolites are products from $M$ factory (Schlanger, 2005).

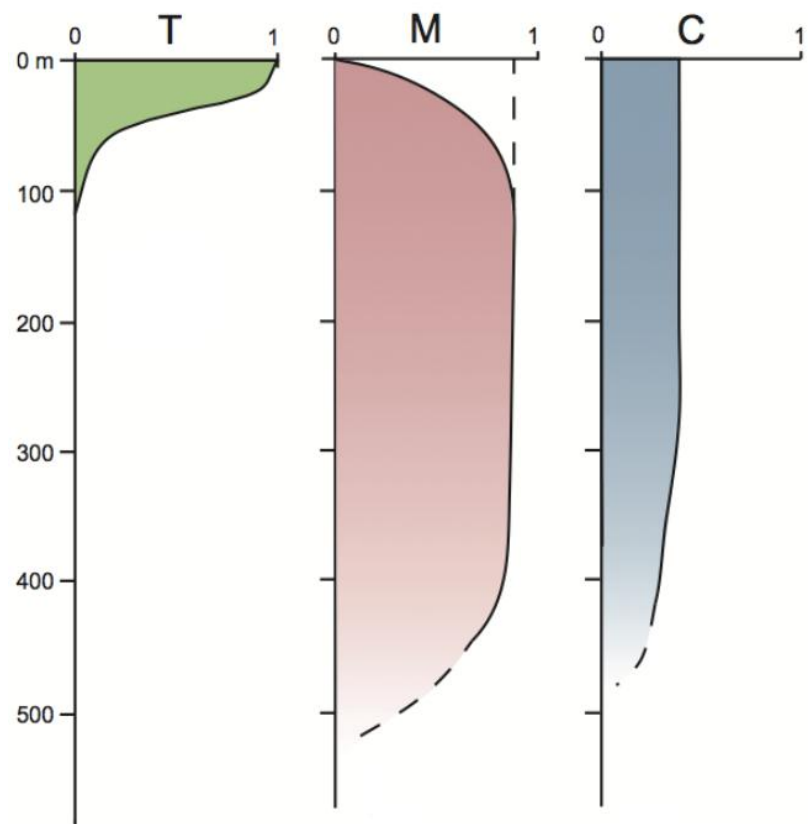

Figure 2 - Carbonate factory's production rate. After Schlanger (2005).

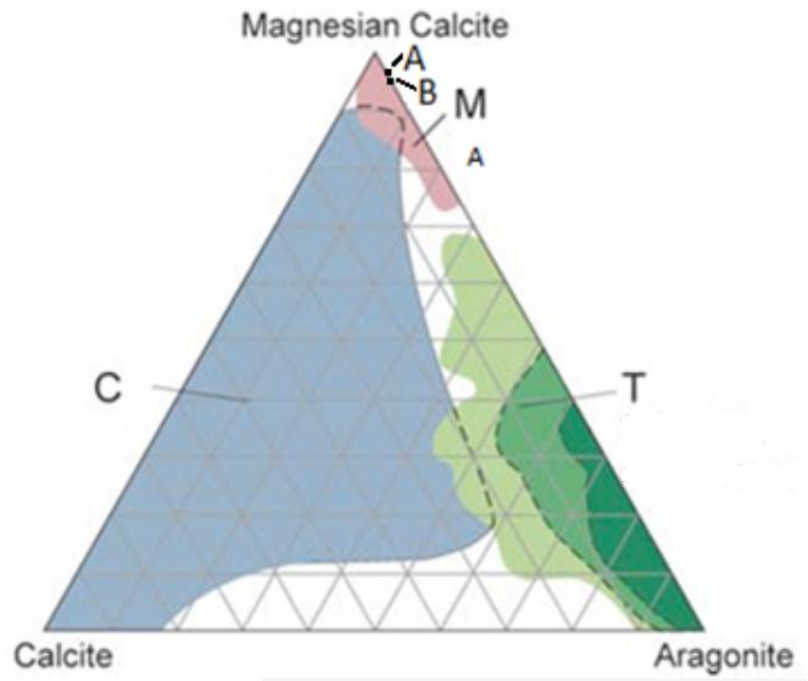

Figure 3 - Mineralogical composition and the carbonate factories. After Schlanger (2005).

\section{Experimental techniques}

A X-ray diffractometer was used to perform the mineralogical characterization. It was used $0.02^{\circ}$ as the step angle and 10 seconds per step as the scanning rate, so the data refinement could be done using the Rietveld method. This data refinement determined the mineralogical quantitative and also the atomic occupancy factor, this last one necessary for magnesian calcite characterization.

Scanning electron microscopy measurements were performed with tension of $20 \mathrm{kV}$, achieving magnifies up to 5000 times. Energy dispersive X-ray spectroscopy (EDS) was used along with it for sample chemical characterization.

Petrographic thin sections were observed with an optical microscope, with magnifies from 25 to 1000 times. This technique enabled observation and analysis of pores, grains and recrystallization regions.

The equipment used to determine the sample porosity was a gas porosimeter that determines the pore volume by expanding gas through the sample, based on Boyle's law.

The rock physics system allowed the determination of the $P$ wave traveltime on the rock sample and, thereby, the determination of this wave's velocity $(V p)$.

\section{Experimental Results}

It was studied two stromatolite samples of different regions (similar to Figure 1, regions $\mathrm{A}$ and $\mathrm{B}$ ). Figure 4 shows the Rietveld plots generated by these samples analysis, in which the black dots are experimental measurements, with the red line showing the refinement adjustment. It was possible to carry out a quantitative mineralogical determination, and estimate the calcium and magnesium occupancy factor for magnesian calcite. These data are shown in both Table 2 and Table 3 .

Table 2 - Stromatolite mineralogy. The numbers in parentheses are errors obtained from data refinement.

\begin{tabular}{|c|c|c|c|}
\hline Sample & $\begin{array}{c}\text { Magnesian } \\
\text { Calcite (wt\%) }\end{array}$ & $\begin{array}{c}\text { Quartz } \\
\text { (wt\%) }\end{array}$ & $\begin{array}{c}\text { Aragonite } \\
\text { (wt\%) }\end{array}$ \\
\hline A & $91.68(3)$ & $5.2(1)$ & $3.2(2)$ \\
\hline B & $93.29(6)$ & $2.2(2)$ & $4.5(2)$ \\
\hline
\end{tabular}

Table 3 - Occupancy factor of calcium and magnesium in the magnesian calcite.

\begin{tabular}{|c|c|c|}
\hline Sample & Calcium (\%) & Magnesium (\%) \\
\hline A & $91.4(8)$ & $8.6(9)$ \\
\hline B & $95.0(7)$ & $5.0(8)$ \\
\hline
\end{tabular}

As the results of mineralogy of the two samples were very similar, SEM measurements were performed only with Sample A, which better suits the equipment requirements to reach vacuum. This sample was coated with gold to make it conductive and enable measurements. Figure 5 shows the SEM image. Chemical analysis showed the presence of atoms of magnesium, calcium and silicon, as highlighted in Figure 6.

Thin sections micrographs are shown in Figure 7 (sample A) and Figure 8 (sample B). In both cases it was possible to observe skeletal materials, quartz grains and pores of 
different formats. Sample B have some regions that suggested recrystallization (Figure 8c and 8d).

The porosity measured with the gas porosimeter is $20.6 \%$ and P-wave velocity measured by the rock physical system is $3076 \mathrm{~m} / \mathrm{s}$.

\section{Conclusions}

The mineralogical result shows that stromatolites are composed mainly by high magnesian calcite (HMC), as the concentration of $\mathrm{MgCO} 3$ is higher than $4 \mathrm{~mol} \%$ in both samples, with small amounts of quartz and aragonite.

Chemical analysis obtained from EDS/SEM showed that the sample chemical elements are the same that constitute the rock minerals.

The aragonite mineral, presented as skeletal materials, and some quartz grains were observed over the thin sections using optical microscopy and confirmed by XRD. The blue regions (Figures 7 and 8) show pores of different sizes and shapes, some of them suggesting the presence of channels (Figures $7 \mathrm{~b}$ and $8 \mathrm{~b}$ ).

The measured porosity of $20.6 \%$ was expected for limestone, but the velocity obtained $(3076 \mathrm{~m} / \mathrm{s})$ is out of the range determined in literature. As the sample was poorly consolidated, then probably the rock elastic properties were affected and so the lower velocity value obtained may be explained.

Finally, based on the mineralogy, it was possible to locate samples A and B in ternary diagram (Figure 3 ). This result was found in accordance with the literature, as the stromatolite is a M factory product.

Further on this research, some measures of X-ray tomography will be performed in order to determine porosity, pore size distribution and investigate the geometry of pores and grains. All these experimental data will be used as input parameters to a rock physics modeling. It will drive into the estimation of $P$ and $S$ wave velocities. To validate this study, a comparison of the estimated and measured (rock physics system) velocities values will be conducted.

\section{Acknowledgments}

The authors thank CAPES, Petrobras and LENEP/UENF for funding the study and the laboratory technicians: Adrielle, Evandro and Remilson for helping the experimental measurements.

\section{References}

Altermann, W., Kazmierezak, J., 2003. Archean microfossils: a reappraisal of early life on Earth: Research in Microbiology, vol. 154: 611 - 617 .
Dürrast, H., Siegesmund, S., 1999. Correlation between rock fabrics and physical properties of carbonates reservoir rocks: International Journal of Earth Sciences, vol. 88: $392-408$.

Estrella, G. O., 2008. Pré-sal: conhecimento, estratégia e oportunidades. In: Fórum Nacional/INAE.

Papaterra, G. E. Z., 2010. Pré-sal: conceituação geológica sobre uma nova fronteira exploratória no Brasil. Master Thesis, UFRJ.

Rafavich, F., Kendall, C. H. St. C., Tood, T. P, 1984. The relationship between acoustic proprieties and the petrographic character of carbonate rocks. Geophysics, v. 49, p. $1622-1636$.

Schlager, W., 2005 Carbonate sedimentology and sequence stratigraphy. Tulsa: SEPM - Society for Sedimentary Geology.

Vanorio, T., Scotellaro, C., Mavko, G., 2008. The effect of chemical and physical processes on the acoustic properties of carbonate rocks. The Leading Edge, v. 27, p. $1040-1048$. 

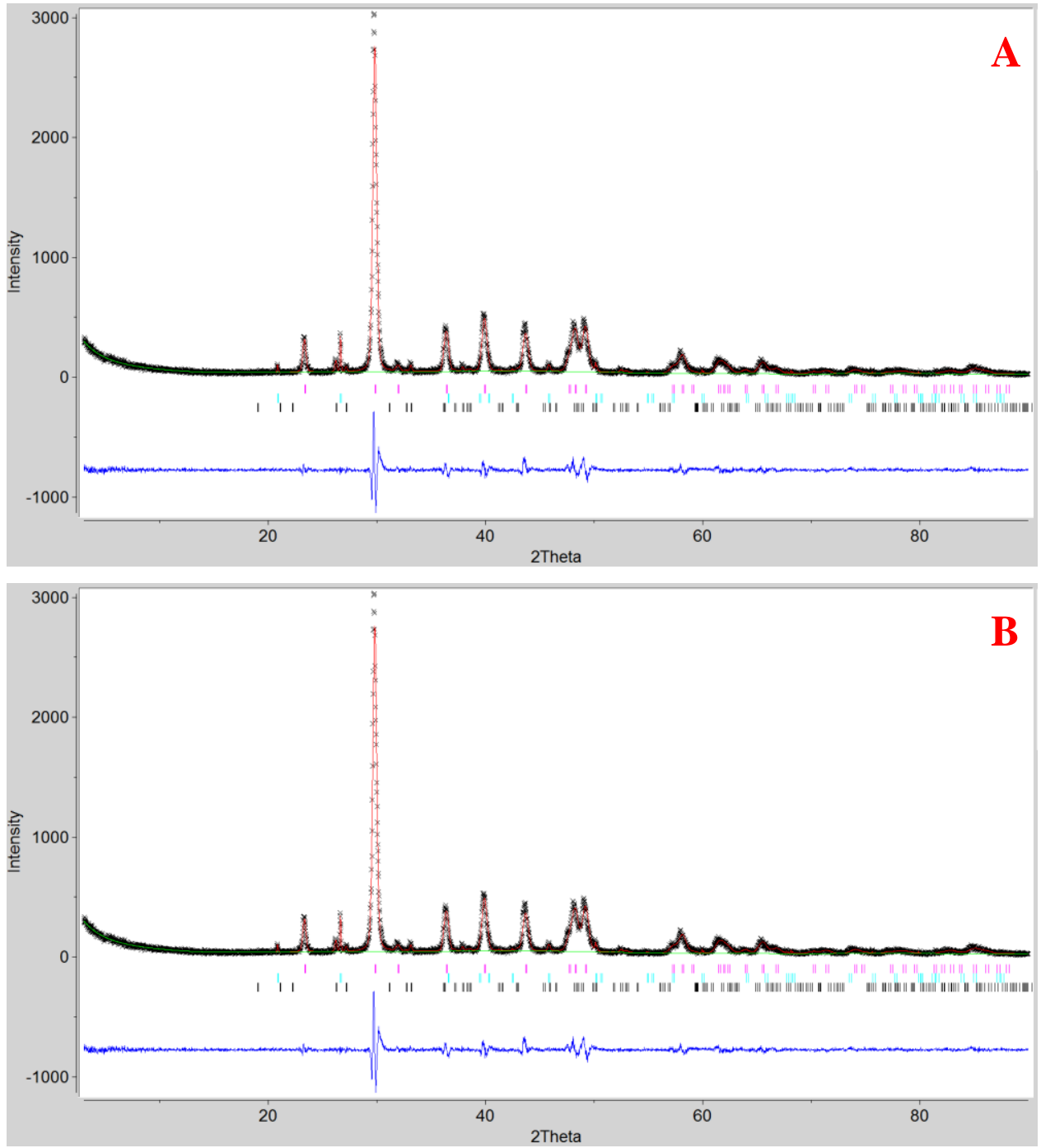

Figure 4 - Rietveld plots for the two samples of stromatolites: Sample $A(A)$ and sample $B(B)$. The minerals presents in this rock are magnesian calcite (magenta), quartz (cyan) and aragonite (black).

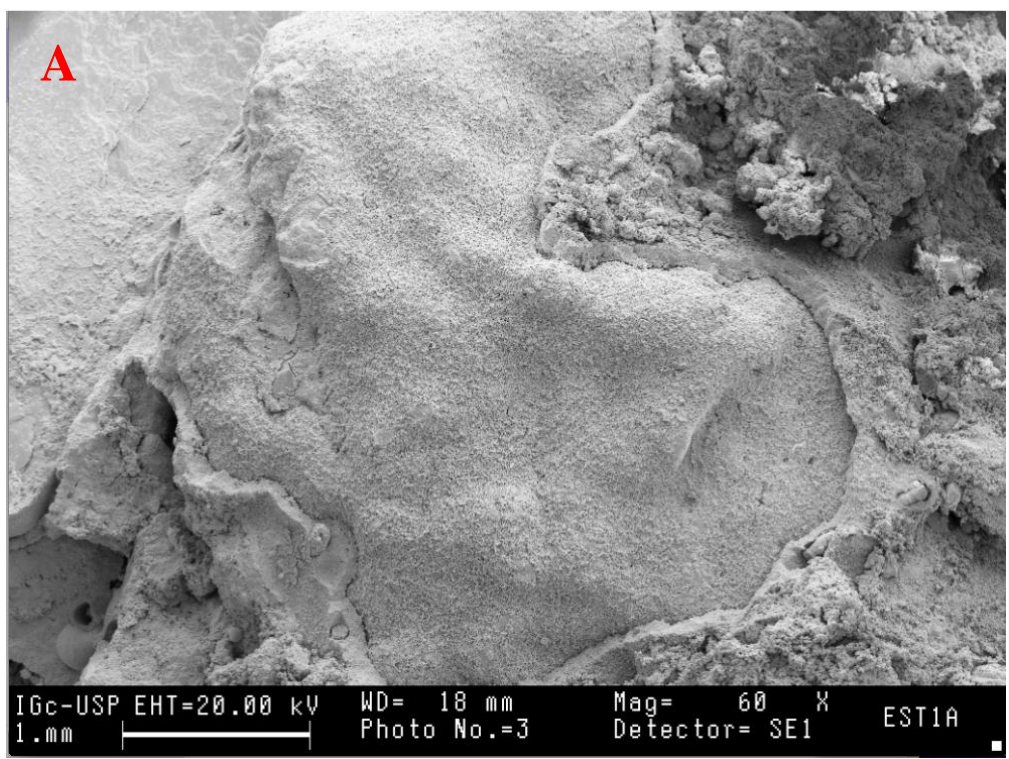




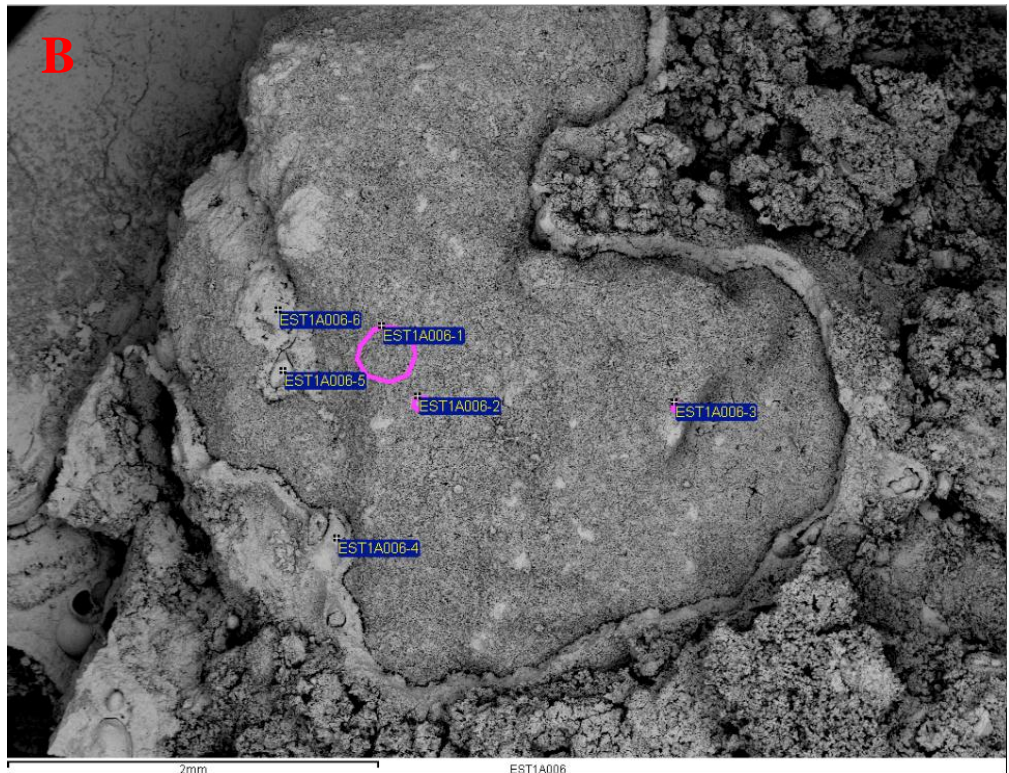

Figure 5 - SEM images of stromatolites with magnifies of 60 times (A). The same image obtained by EDS for sample chemical characterization (B).
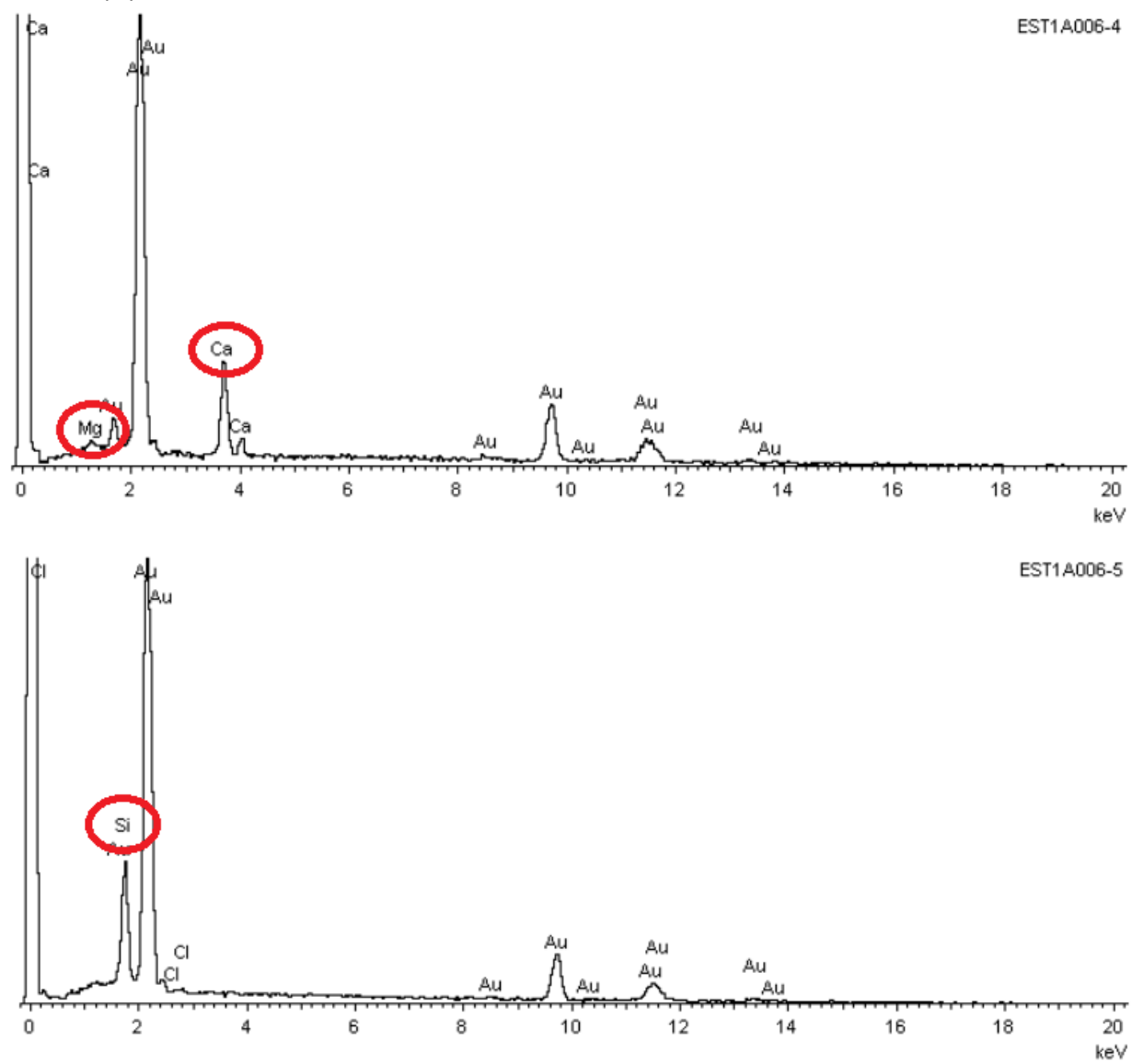

Figure 6-Chemical analysis of two stromatolite regions (Figure 4 B). Note the presence of magnesium, calcium and silicon, the chemical elements that compose magnesian calcite, aragonite and quartz. 

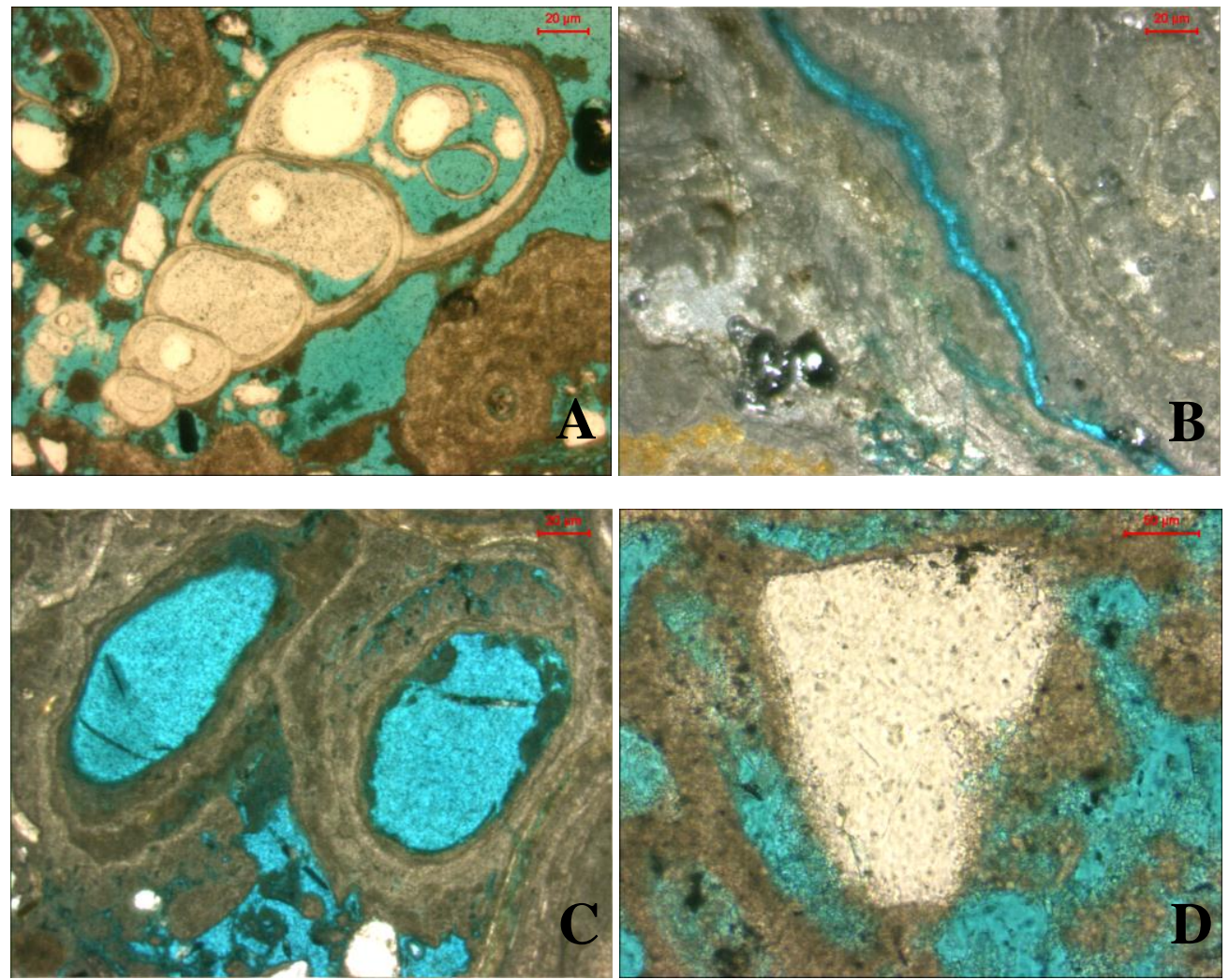

Figure 7 - Thin sections from sample $A$. It possible to observe skeletal material $(A)$, different pores types $(B, C)$ and a quartz grain (D).
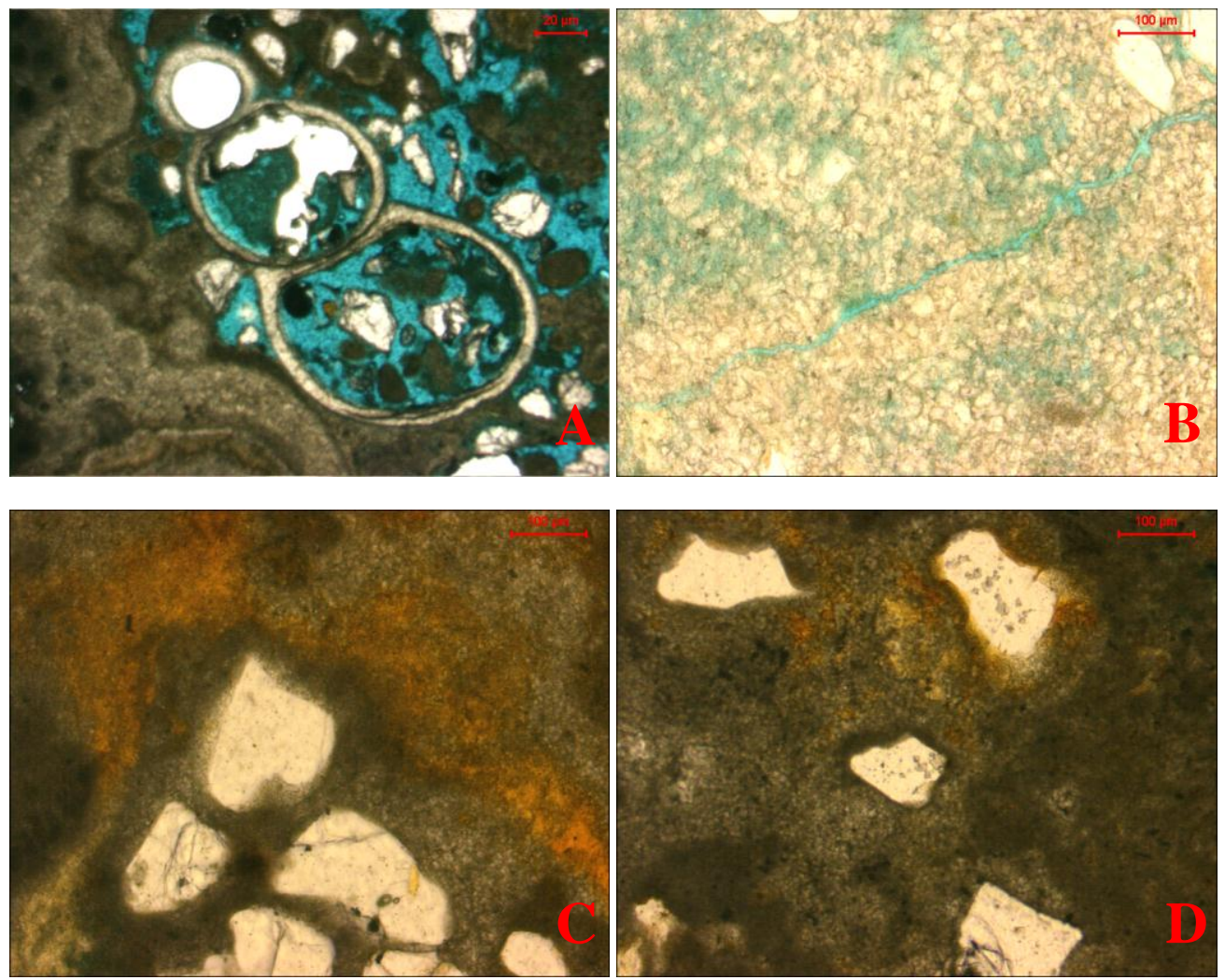

Figure 8 - Thin sections from sample B. It possible to observe skeletal material (A), small pores and a channel (B), quartz grains (white $-C, D)$ and recrystallization regions $(C, D$-gold regions). 